\title{
COMMUNITY INVOLVEMENT AND ACADEMIC RESPONSE: THE UNIVERSITY OF ADELAIDE ABORIGINAL RESEARCH CENTRE
}

\author{
Fay Gale
}

Early in 1979 John Austin, who was then Director of the Aboriginal Community Centre in Adelaide, approached the University of Adelaide with a request to establish a communitybased research unit within the University. Informal meetings were held between representatives of Aboriginal groups, academics who were already involved in Aboriginal research at the University and the Vice Chancellor. These led to a formal submission being put to the University Council at the end of 1979.

The proposal recommended that a centre be established whereby Aborigines in the community could have access to the skills and knowledge of academic specialists in a number of fields and in ways not readily available to them previously. It suggested that past research had been initiated largely by non-Aborigines without Aboriginal involvement or consultation in many cases. Often students undertook studies without Aboriginal approval. As one Aboriginal member of the committee said, 'We are tired of being researched; we want to be in the research ourselves, to have a say in what needs to be studied'.

For the University Council the recommendations' were somewhat unusual. The University was being asked to set up a research base where academics would not have sole control of the research decisions. Projects would be formulated outside academic circles. Research would be judged by two criteria not usually accepted: how useful the results might become and how Aborigines would be involved at all stages of planning and implementing the research. It was very much applied research and Aborigines would be learning research skills at the same time as they were making significant contributions to each project.

The concept was accepted by the Council and a committee consisting of equal numbers of academic staff and community-based Aborigines was appointed. The first meeting of this committee was held at the University on 4 th February 1980. The aims written down at that meeting are summarised as follows:

1. The prime aim is to undertake research requested by Aboriginal organisations.

2. To make it possible for groups to have independent studies and evaluations made that would not be bound by any government or agency direction or finding.

3. To make sure that the findings of such studies are fed back to the Aboriginal groups.

4. To involve Aboriginal people in each research project.

5. To make sure that the participating Aboriginal people learn the skills involved in doing research.

6. Informally to act as a training centre for Aborigines in various agencies who wish to acquire skills for use in preparing reports and submissions.

7. To help Aboriginal groups which request assistance to set up statistical or computer systems, judged to be of increasing importance to the survival of independent Aboriginal agencies.

8. To assist Aborigines to gain entry to University as full-time students.

9. To make available facilities for conferences and workshops.

10. To prevent overlap of research in projects, to introduce prospective research students to the committee and to allow Aboriginal members, in consultation with their groups, to accept or reject research proposals.

These aims were seen to be quite comprehensive and the committee considered that it would be wise to start somewhat slowly especially as the Centre's resources were limited. Some goals were achieved quite early. The University changed its special entry provisions to allow non-matriculating Aborigines to enter the University at the beginning of 1981. As a result eight have become full-time students, three in law and five in arts. This was a big breakthrough for a university which has had no Aboriginal graduates. In addition two 
students, one in science and one in mathematical science, have been admitted under normal matriculation requirements.

The Research Centre acts as a social focus for these students and tries to keep them in touch with both campus activities and Aboriginal community groups. Aboriginal staff (a research worker and a secretary) facilitate the process. The Centre has become a haven on a campus of 'all white faces'.

The initial research goals were defined in terms of urgent projects. A workshop, organised by the Aboriginal Training and Cultural Institute of Sydney, was held early in the program to work out priorities. Mrs N. McNamara, who is co-director of the Institute, is also a member of the Research Centre committee. She conducted the workshop and produced a report on research needs and directions as viewed by Aboriginal people in South Australia.

The first project to be defined and taken up was one on young offenders. Representatives of the Aboriginal Community Centre, the Aboriginal Child Care Agency and the Aboriginal Legal Rights Movement viewed the high proportion of young Aborigines coming before the courts as a major concern. They also saw it as a very complex legal and social issue which needed detailed study. At the request of community representatives the Aboriginal Research Centre approached three academics (in Education, Geography and Law) to set up an interdisciplinary study. The project gained A.R.G.S. funding. An Aboriginal member of the committee, Mrs M. Van der Byl, undertook the major part of the interviewing for study and worked closely with the academics.

The issue has indeed proved to be a complex one and research is continuing. Justice does not operate equally for all Australians and in spite of the establishment of Aboriginal Legal Rights offices, Aboriginal youth are still over-represented to an extreme degree in the court system. The research to date suggests there is no evidence to show that Aboriginal youth are any more anti-social or more criminally motivated than are non-Aboriginal youth. The procedures, the statistics and all the forces at work combine to misrepresent the true situation. The researchers believe it is important for the self-respect of Aborigines that their image as offenders is put more accurately than is presently revealed in published records and media reports.

Doreen Kartinyeri, an Adelaide resident who had earlier lived on both Point McLeay and Point Pearce reserves, became the first full-time member of the research staff at the Centre. She had already commenced work on a genealogical program with funding assistance from the Australian Institute of Aboriginal Studies and the Aboriginal Arts Board. The new Centre was able to provide her project with resources in terms of accommodation, materials and personnel. A historian was appointed to work with Ms Kartinyeri and between them they have been able to merge the knowledge contained in an oral tradition with the skills of interpreting written records and recording verbal material. The extensive work done so far and the response being received from Aboriginal people illustrate the value of Aboriginalinitiated programs. This ambitious study has three research components. One is recording genealogies of the main Aboriginal families in southern South Australia To date the Rigney family contianing some 900 members and the Wanganeen family with over 850 persons have been typed up. Individual names have been indexed so that descendants can trace their ancestors. The collection of details for another thirty-one families is in progress. Because of the interrelatedness of information on families, much material is collected simultaneously so that work on a number of families proceeds at the same time. Some halfdozen have been finished or are nearing completion.

A second aspect of Ms Kartinyeri's research is the collection, indeed often the salvage, of old photographs of Aborigines in southern South Australia. The identification of people and places recorded in such photographs is very slow, painstaking and sometimes requires a great deal of travel to check with informants. But in many cases these photographs capture unique aspects of the social history of Aborigines in southern South Australia. The University has reproduced these photographs for Ms Kartinyeri and she has been meticulous in returning the originals, along with the produced negatives and spare copies of prints, to the persons who gave them to her. The production of good prints from old photographs has 
enabled Ms Kartinyeri to make displays which she has taken to a number of centres. The interest generated is considerable. A sense of identity and pride in the local history is fostered and more photographs and information are forthcoming as a result. For National Aborigines Week, 1982, the people of Point Pearce decided to set up a display in the hall at the reserve depicting the history of the settlement and its people. They called on Ms Kartinyeri, who had lived on the reserve for much of her life, for assistance. She both acted as a consultant and helped to establish displays of her photographs. These were arranged in sections, such as 'Early settlement', 'Farming on the mission', 'Families at Point Pearce', 'Children and schools' and 'Early pioneers'. Several hundred people attended the exhibition from many parts of the State and overseas and many questions were asked about people and happenings in the early days of the mission.

The third phase of the research consists of a series of descriptions of aspects of the lives of the people being recorded in the genealogies and photographs. The material is obtained from oral sources as remembered by Ms Kartinyeri and the people she works with. Various written sources such as those available at the South Australian Museum, the State Archives and the Registrar of Births, Deaths and Marriages are used to relate and co-ordinate oral material. When the Aboriginal Research Centre was established it was anticipated that the unit would function as a resource centre as well as a research group. Ms Kartinyeri's work has shown that to be true. Her genealogies have provided a source for those Aborigines who had lost contact with their people. In South Australia, as elsewhere, welfare authorities in earlier days saw it as their duty to remove young children from their mothers and place them in institutions or foster care or place them out for adoption. In most cases such young children grew up in non-Aboriginal homes and lost contact with their relatives.

For many young people this paternalistic program of earlier years produced considerable emotional strain and conflict. The results are still being experienced amongst teenagers and young adults although officially that program has been abandoned. But the long-term results did not end with the change in welfare policy. The search for kin is now very strong. Ms Kartinyeri has had a steady flow of inquiries from young people wishing to find their families and from mothers wondering what happened to the children they lost. Her detective-like skills in searching out relationships is quite uncanny. She has reunited several families with great joy and benefit to all concerned. In one case a couple who were contemplating marriage consulted Ms Kartinyeri about their true identities. Both had been adopted at birth and did not know their natural parents. Ms Kartinyeri found that in fact they were very closely related and had they not been adopted and their true parentage lost they would not have contemplated marriage. They were very pleased 'to find out in time' and to learn about families they had never known. The research is thus helping to overcome some of the complex problems which have resulted from former welfare policies to which Aborigines were subjected.

There is a growing interest amongst younger Aborigines in their historical roots and not only amongst those whose links were severed by fostering or adoption. There is an increasing concern to know more about the past, a past which so inextricably links Aboriginal and non-Aboriginal experiences, values and attitudes. As Doreen Kartinyeri has taken examples of her work to various communities, groups have begun to request training in collecting and recording their local histories. Plans are under way to develop such programs at the Centre in 1983 and several people have asked to attend these proposed workshops.

Since the establishment of the Aboriginal Research Centre and the deliberate policy of introducing non-Aboriginal researchers, including students, to community groups a growth of exchange has evolved. Some Aborigines have come to see that research need not be yet another piece of 'white man's domination'. It can be a two-way process with advantage accruing to both parties. As a result the Centre has been asked to search out various sources and let Aboriginal people know what written records might be available for them to study. For example, interested Aborigines have requested information about the Basedow and Bates collections held in Adelaide libraries. Others also want to know what kinds of material may help them to learn more about the past experiences of their particular groups. 
Jane Jacobs, whose project was the first to be introduced to the Centre Committee, has worked closely with committee members. Her study has been supported by the Australian Institute of Aboriginal Studies. The starting point for her research was the inadequacies of land rights legislation at present in use. She argued that the Aboriginal Land Rights (Northem Territory) Act 1976 and the Pitjantjatjara Land Rights Act 1981 set precedents for the interpretation of land rights based on the concept of 'Aboriginality': the more traditional the community the more deserving they are of land. Such legislation has created a model based more on defining traditional 'Aboriginality' than concern for the realities of the contemporary Aboriginal land legislation. Ms Jacobs' study of land rights amongst the 'non-traditional' people of the Port Augusta area has been a very complex project. It has progressed well because of this student's commitment to feedback to Aboriginal groups and to mutual respect and exchange of ideas. Some academics might consider that such a process slows down research (if success is measured in terms of time taken to get a degree or produce publications). But the depth of the resulting research, and the benefit to the groups concerned far outweigh the supposed costs. Jacobs' research has been a two-way venture and it has shown that academic research properly carried out can be an important resource for an Aboriginal group.

When another potential post-graduate student approached the Centre with a project it was referred to, and rejected by, the community concerned, which did not want to have such research carried out at that time. Therefore the project did not go ahead. The Centre felt that this experience was valuable because it showed that the University would accept a community's refusal even though the group had no land rights or power in legal terms.

The Centre has been approached at other times by various groups and organisations seeking studies of particular events or places. One Aboriginal member of the committee, who is also a member of a community liaison body looking at the problems of Aboriginal youth in Adelaide, asked the Centre to consider a study of young people in Hindley Street. This area is the major social scene for Aborigines in Adelaide and young people come great distances to interact here. Aboriginal community workers and welfare staff wanted to know why so many young Aborigines come to this locality, who comes, how they relate to each other and whether the opportunity to achieve identity and a sense of 'groupness' outweigh the risks posed to them from the socially disadvantageous activities engaged in by nonAborigines in the area. Through discussion with involved groups a study project was set up and graduate students were introduced to the work.

Other students were asked to record in detail the political and bureaucratic difficulties faced by the Aboriginal Community College in its attempt to move its location. Public action, planning appeals and eventually arson bedevilled various attempts to re-locate the College in a better facility. The College Council considered it would be useful to have these events documented in a chronological sequence for future reference.

As the requests for projects increased it became evident that the need for a research and resource base was indeed as great as John Austin's vision had predicted. The committee was enlarged so that all Aboriginal groups and organisations in Adelaide could be represented. Aboriginal membership is now twice the size of the non-Aboriginal academic representation. This is very important because the Centre has recently been approached by government departments and asked to undertake consulting work related to Aboriginal communities and organisations. Such requests can now be very carefully discussed by groups with widely-based support across the Aboriginal community,

In some ways the Centre has acted as a neutral forum for the expression of ideas and dissatisfactions. Academic specialists have been called in from various areas to offer advice and to assist with action programs. One such case was the reading of the Pastoral Act Amendment Bill 1982 in the South Australian Parliament. Concerned Aborigines requested the Centre's assistance in making their case. They were worried that the proposed legislation would limit Aboriginal access to traditional lands and prevent further land rights claims. Meetings were held, academic lawyers gave advice and wrote submissions and the Centre 
was able to put forward submissions to the government which helped in defeating the proposed Bill. In this case the Centre, its committee considerably augmented for the purpose, worked in close conjunction with the Aboriginal Legal Rights Movement.

Universities have traditionally provided a relatively neutral environment for unhampered research. The Aboriginal Research Centre at the University of Adelaide can offer resources such as 'neutral territory', training, and expert advice on request. These things are particularly important to Aborigines, who have had limited educational opportunities and little access to sophisticated technology and specialist skills, and who feel themselves tightly controlled by outside pressures. The Aboriginal concept of this Centre vests power and decisionmaking in a consultative process. But is this concept too threatening to non-Aboriginal institutional structures to enable the Centre to obtain the funding it needs to survive? 